\title{
EXPERIENCE VEGETATIVE PROPAGATION RUSSIAN OLIVE (ELAEAGNUS ANGUSTIFOLIA L.) IN UZBEKISTAN
}

(C) Turdiev S., Tashkent state agrarian university, Tashkent,Uzbekistan,alp.lentinus@gmail.com,tuag-info@edu.uz

\section{ОПЫТ ВЕГЕТАТИВНОГО РАЗМНОЖЕНИЯ ЛОХА УЗКОЛИСТНОГО (ELAEAGNUS ANGUSTIFOLIA L.) В УЗБЕКИСТАНЕ}

(СТурдиев С. А., Ташкентский государственный аграрный университет, 2. Ташкент, Узбекистан, alp.lentinus@gmail.com,tuag-info@edu.uz

Abstract. Conducting the results of the research work on the studies optimal timing of harvesting and planting stem cuttings Russian olive. The formation of adventitious roots on cuttings Russian olive is dependent on callus. The roots are laid in the cambium of the stem cuttings and breaking through the crust near the pillow or sheet between the callus and bark. Cuttings Russian olive autumn harvesting and spring planting at the end of the growing season gave the best gain in height $-166.7 \pm 5.35 \mathrm{~cm}$ (diameter of $10.2 \pm 0.47 \mathrm{~mm}$ ). Annuals plants from cuttings Russian olive autumn harvesting had $30 \mathrm{~cm}$ long and a height of $179.8 \pm 5,09 \mathrm{~cm}$ (diameter of $11.1 \pm 0.69 \mathrm{~mm}$ ) and save $88 \%$. The best survival was observed in the cuttings, prepared with annual shoots. By the end of vegetative growth leading to escape the majority of seedlings Russian olive reaches $83-166 \mathrm{~cm}$ in height. Maximum 160-221 cm.

Аннотащия. Приводятся результаты научно-исследовательской работы по изучению оптимальных сроков заготовки и посадки стеблевых черенков лоха узколистного. Формирование корневых волосков зависит от каллуса. Корни образуются не только с базальной части стеблевого черенка, но и из камбия и прорываются сквозь кору возле почки. Черенки заготовленные поздней осенью и посаженные весной укоренились лучше и в конце вегетации имели высоту 166,7 $\pm 5,35$ см (диаметр 10,2 $\pm 0,47$ мм). Однолетние саженцы, выращенные из черенков осенней заготовки длиной 30 см имели лучшую высоту $179,8 \pm 5,09$ см (диаметр 11,1 $\pm 0,69$ мм) и сохранность составил $88 \%$. Наилучшие сохранность саженцев наблюдалось у черенков, заготовленных с однолетних побегов.

К концу вегетации укоренные саженцы лоха узколистного имели высоту 83-166 см. Максимум высоты наблюдался 160-221 см.

Keywords: gene pool, selection, promising forms, stem cuttings, callus, own-rooted seedlings.

Ключевые слова: генофонд, отбор, перспективные формы, стеблевые черенки, каллус, корнесобственные саженцы.

\section{Introduction}

Our civilization has been closely associated with the introduction of the culture of wild plants and their subsequent selection on productivity and product quality. From the appearance of man on earth, and to this day they are invariably played an important role in his life. 
Russian olive (Elaeagnus angustifolia L. = orientalis L.) are the most important members of the family of oleasters (Elaeagnaceae) - oleaster (Elaeagnus), these plants differ from each other outward form - the height of trees or shrubs, size and shape of the crown, as well as the quality and structure of their fruits.

Fruits of Russian olive for centuries have always had food value in the air-dry pulp contains up to $40-62 \%$ sugar, up to $11 \%$ of proteins, to $2.46 \%$ of organic acids and up to $200 \mathrm{mg}$ vitamin $\mathrm{C}$ and valuable medicinal preventive properties Russian olive has long been known in folk medicine in many Asian and Caucasian countries.

Russian olive grows in a hot, dry and continental climate, on moist or wet places. As a result of long-term culture and selection, local growers have identified many good varieties Russian olive large-fruited that differ valuable properties: high yield, good quality fruit, salt-tolerant and drought resistance.

Breeding work and working methods of vegetative propagation of promising forms of Russian olive have great prospects. It will enrich the range and biodiversity posed by plantations and orchards. Ability sucker for vegetative reproduction allows to easily laid the valuable plantations of the best forms. The best way of vegetative reproduction - is the stem multiplication or rooting hardwood cuttings.

\section{Materials and methods}

Uzbekistan is rich in local varieties and forms of fruit crops cultivated species.

In recent years, increased interest in Russian olive as a medicinal form. Deserves researches E. A. Abizov [1] to establish the medicinal value of various types of Russian olive, the possibility of their culture in the southern regions of the Russian Federation and the rational use as a medicinal plant. Conducting a phytochemical analysis of fruits, overground and underground parts. From various organs of Elaeagnus isolated end identified 41 biologically active compounds. Found high levels of molybdenum and nickel in Elaeagnus leaves.

In order to identify its most promising forms of folk selection Russian olive forms were selected according to the method developed by the All-Russian Scientific Research Institute of breeding of fruit crops in 1999. "Program and methods Cultivar fruit, berry and fruit and nut crops" (Edited by Acad. E. N. Sedov). Total selected in different regions of the Republic of 87 plus trees, from them on the basis of evaluation of breeding evolution allocated 27 perspective forms from which later on vegetative propagation were obtained seedlings clones [3-4].

\section{Results and discussion}

Study of the optimal timing of planting and harvesting hardwood cuttings Russian olive impact of their size on the survival and growth of seedlings. Cuttings harvested in two deadlines: the end of November and in early March. Woody shoots are harvested with highly productive, large-fruited, healthy and resistant to pests and diseases of trees. For cutting cuttings used the middle part of the shoots.

Cuttings are cut in such a way that the cut was somewhat oblique, smooth, and bark is not behind the wood. The lower section made directly under the kidney, the upper 1-2 $\mathrm{cm}$ above. In experiments tested cuttings length of 15,20, 25 and $30 \mathrm{~cm}$. Intended for planting cuttings in the spring, harvested in the autumn of the previous year, it was stored in the trenches to a depth of 0.5 $\mathrm{m}$ in the moist soil.

Related bundles of cuttings in the basal (lower) part put in a loose, slightly moist coarse sand on the bottom of the trench. When storing the cuttings in this mode, the internal tissues of the stalk 
forming meristematic pockets, and laid the beginnings of the future of adventitious roots. The soil is prepared in the autumn on the depth of $28-30 \mathrm{~cm}$.

\section{Russian olive}

Cuttings planted vertically under the peg. The distance between rows of $60 \mathrm{~cm}$, and rows 12 cm. (138888 pcs./ha). Planting hardwood cuttings is carried out in early march in loose fertile and cultivated deep light soil. The cuttings are planted on rooting in such a way that on the soil surface was 2.3 kidneys. The leaves of the cuttings are dismissed before the roots are formed. Soil Moisture first $4-5$ weeks of growing seedlings maintained at $45-60 \%$ by weight of dry soil, the next at 30 $35 \%$. Education growth of the upper kidney with 4-5 nodes on it means that hardwood cuttings have begun to take root.

It was found that the cuttings Russian olive characterized by a high regenerative capacity in their rooting in open field conditions. In parts of the stem sucker shoots weakly expressed at cambial activity associated with the rapid emplacement, and then the operation of the secondary meristem cambium. Lignification cambium derivatives, largely expressed in the basal (lower) part of the stem, can directly or indirectly influence the processes subordinate root formation [2].

In the early stages of propagation on the stem of the cutting will soon appear adventitious roots and the subsequent radial growth of the stem a little distinguishable from the root growth. However, at later stages of propagation and use the bottom of the shoots, the process proceeds longer, being observed the intensive development of callus with simultaneous local thickening of the lower part of the stem cuttings.

Ring callus becomes more convex and extends laterally cortex, i.e. in the longitudinal section across the ring callus tissue grows down and centrifugal, gradually occupying the entire lower edge of the area, which in turn also increases due to the radial thickening of the stem.

Callus develops mainly due to the activity of the cambium. Participation of other living tissues is shown depending on the degree of lignification and the general state of the cutting age. Duration of callus growth, its size and shape depending on the size of the cuttings, the content of nutrients starts and finally the emergence of roots from the external environment. The formation of adventitious roots on cuttings Russian olive is due to callus.

As a rule, roots are laid in the cambium of the stem cuttings and breaking through the crust near the pillow or sheet between the callus and bark. Survey and study of annual seedling root systems feature Russian olive showed that the length of lateral roots of $50-55 \mathrm{~cm}$. Adventitious roots develop not only from the callus, but the roots are also placed in node and internode, or on the cut surface and interstitial.

In cuttings sucker roots arranged in rows along the trace of the sheet or in the vicinity of his around. This is obviously due to the great development here meristematic tissue and the best of their supply of nutrients coming from the leaves.

\section{Conclusions}

Caring for the planted cuttings is watering, weeding and loosening the soil. The resulting increase rapidly increased in the second half of the summer. Shoots develop unevenly, usually from the upper 2.3 kidneys. The leading is becoming one of them, others gradually stop growing. On the leading summer escape often, develop side shoots. The growth of seedlings from cuttings depends on the size and timing of the work piece. Cuttings Russian olive autumn harvesting, and spring planting gave the best gain in height $-166.7 \pm 4.35 \mathrm{~cm}$ (diameter of $10.2 \pm 0.47 \mathrm{~mm}$ ). Annuals plants from cuttings in Russian olive $30 \mathrm{~cm}$ had a height of $179.8 \pm 5.09 \mathrm{~cm}$ (diameter of $11.1 \pm 0.69 \mathrm{~mm}$ ), from cuttings of $20 \mathrm{~cm}-148.7 \pm 4.25 \mathrm{~cm}$ (diameter $9.9 \pm 0.71 \mathrm{~mm}$ ) Table 1. 


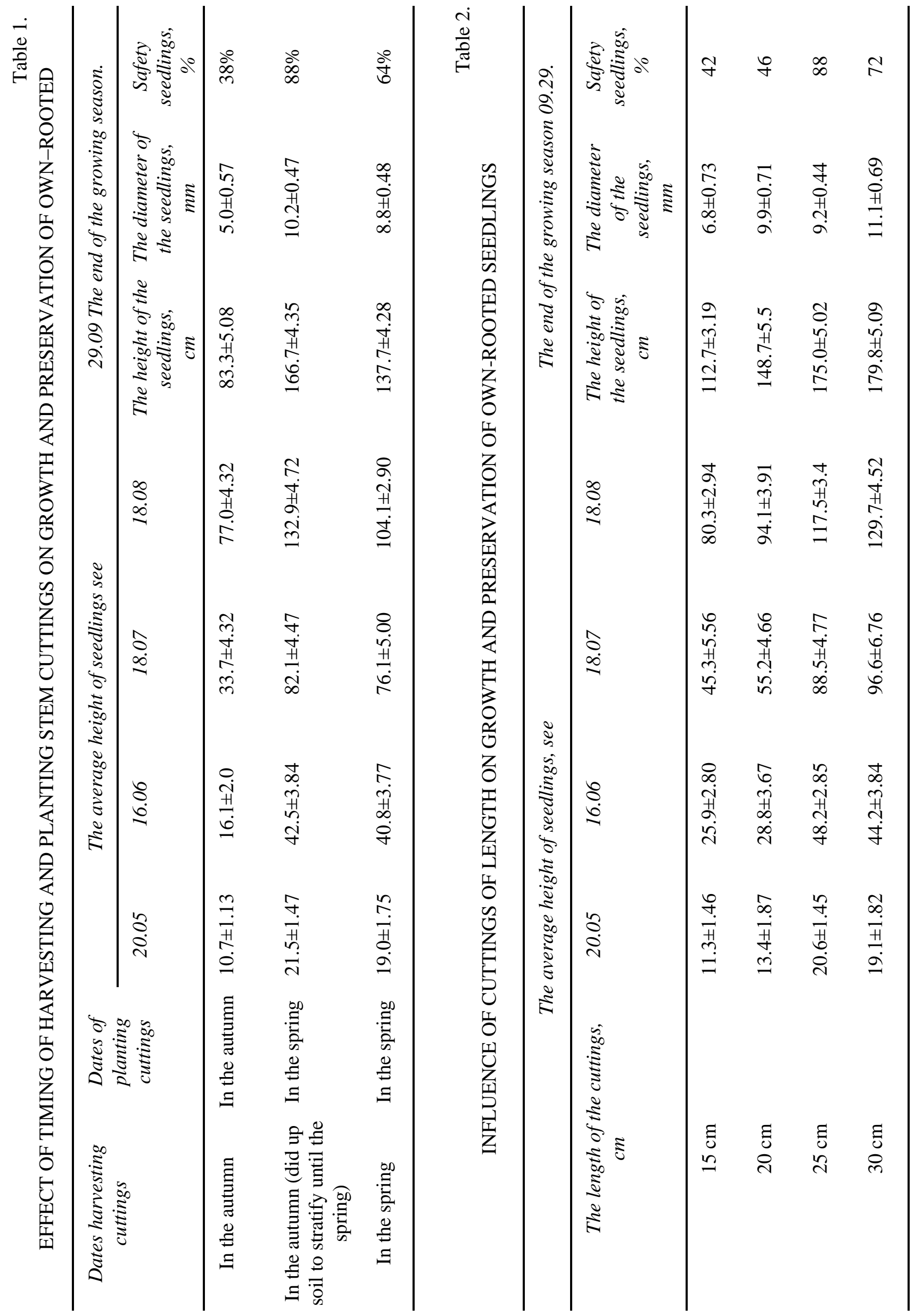


Preservation plants from cuttings autumn harvesting and spring planting was $88 \%$, the spring blank - 64\%. Cuttings length 25-30 cm characterized by high adaptability (88-72\%), cuttings 15 $\mathrm{cm}$ long low survival rate (42\%) Table 2.

The best survival was observed in the cuttings, prepared with annual shoots. By the end of vegetative growth leading to escape the majority of seedlings Russian olive reaches $83-166 \mathrm{~cm}$ in height, maximum 160-221 cm. In the autumn or early spring, harvesting cuttings at vegetative propagation nursery in Russian olive optimal length is $30 \mathrm{~cm}$.

\section{References:}

1. Abizov, S. A. (2012). Biological and chemical-technological substantiation of the medicinal value of species of the genus Elaeagnus L. (Loch), introduced in Russia: authoref. Dr. diss. Moscow, 34. (in Russian).

2. Turdiev, S. A., \& Berdiev, E. T. (2013). Biological basis of vegetative reproduction of sucker and sea buckthorn. Uzbek Biological Journal, (1), 20-23.

3. Sedov, E. N., \& Ogoltsova, T. P. (1999). Programma I metodika sortoizucheniya Popovych, yagodnykh i orekhoplodnykh kul’tur. Orel, VNIISPK, 606. (in Russian).

4. Guilbault, K. R., Brown, C. S., Friedman, J. M., \& Shafroth, P. B. (2012). The influence of chilling requirement on the southern distribution limit of exotic Russian olive (Elaeagnus angustifolia) in western North America. Biological Invasions, 14(8), 1711-1724.

\section{Список литературы:}

1. Абизов С. А. Биологическое и химико-технологическое обоснование лекарственной ценности видов рода Elaeagnus L. (лох), интродуцированных в России: автореф. дисс. ... д-ра фармацевт. наук. М., 2012. 34 с.

2. Турдиев С. А., Бердиев Э. Т. Биологические основы вегетативного размножения лоха и облепихи // Узбекский биологический журнал. 2013. №1. С. 20-23.

3. Седов Е. Н., Огольцова Т. П. Программа и методика сортоизучения плодовых, ягодных и орехоплодных культур. Орел: ВНИИСПК, 1999. 606 с.

4. Guilbault K. R., Brown C. S., Friedman J. M., Shafroth P. B. The influence of chilling requirement on the southern distribution limit of exotic Russian olive (Elaeagnus angustifolia) in western North America // Biological invasions. 2012. V. 14. №8. C. 1711-1724.

Работа поступила

в редакцию 17.01.2019 г.
Принята к публикаџии 21.01.2019 2.

Cite as (APA):

Turdiev, S. (2019). Experience vegetative propagation Russian olive (Elaeagnus angustifolia L.) in Uzbekistan. Bulletin of Science and Practice, 5(2), 159-163. https://doi.org/10.33619/2414$2948 / 39 / 21$.

Ссылка для цичтирования:

Turdiev S. Experience vegetative propagation Russian olive (Elaeagnus angustifolia L.) in Uzbekistan // Бюллетень науки и практики. 2019. Т. 5. №2. С. 159-163. https://doi.org/10.33619/2414-2948/39/21. 